\title{
Prediksi Neraca Air Untuk Menentukan Masa Tanam Tebu di Kecamatan Kalasan, Sleman
}

\section{Prediction of Water Balance to Determine Sugarcane Planting Season in Kalasan District, Sleman}

\author{
Kamelia Dwi Jayanti ${ }^{1}$, Putu Sudira ${ }^{2}$, Bambang Hendro Sunarminto ${ }^{3}$ \\ ${ }^{1}$ Fakultas Pertanian Universitas Sintuwu Maroso, J1 Pulau Timor No.1, Poso \\ ${ }^{2}$ Fakultas Teknologi Pertanian UGM, Jl Flora Bulaksumur, Yogyakarta 5528 \\ ${ }^{3}$ Fakultas Pertanian UGM, Jl Flora Bulaksumur, Yogyakarta 55281
}

\begin{abstract}
Rainfall patterns changes in Indonesia have occurred since the last few decades. This change causes shifting season in some areas. Sugarcane (Saccharum officinarum L.) is a plant that needs a lot of water on the vegetative phase but need dry conditions before harvest. The lack determination of proper planting season can decrease yield even crop failure. The research of Sugarcane planting season determination conducted in Kalasan District, Sleman. This area is rainfed. Rainfall affects the availability of soil moisture in rainfed land. The data used in this study is the monthly rainfall data over the last 10 years (2002-2011), temperature, humidity, wind speed, long exposure, soil physical characteristic and plant data. This study was preceded by generating monthly rainfall data the next 10 years (2012-2022) using the model of ThomasFiering. This generation of rainfall data used to make the water balance. The water balance surplus and deficit describe the condition of soil moisture availability. Data analysis shows that the water balance right sugarcane planting is September-August and October-September.
\end{abstract}

Keywords: Planting Season, Generating Monthly Rainfall Data, Water Balance

\section{INTISARI}

Perubahan pola curah hujan di Indonesia telah terjadi sejak beberapa decade terakhir. Perubahan ini menyebabkan terjadinya pergeseran musim di beberapa daerah. Tanaman tebu (Saccharum officinarum L.) merupakan tanaman yang membutuhkan banyak air pada fase vegetative tetapi membutuhkan kondisi kering ketika menjelang panen. Penentuan masa tanam yang kurang tepat dapat menurunkan hasil produksi bahkan gagal panen. Penelitian penentuan masa tanam tebu dilakukan di Kecamatan Kalasan, Sleman. Daerah ini merupakan lahan tadah hujan. Curah hujan sangat berpengaruh terhadap ketersediaan lengas tanah pada lahan tadah hujan. Data yang digunakan dalam penelitian ini adalah data curah hujan bulanan selama 10 tahun terakhir (2002 -2011), suhu, kelembaban, kecepatan angin, lama penyinaran, sifat fisik tanah dan data tanaman. Penelitian ini didahului dengan membangkitkan data curah hujan bulanan 10 tahun ke depan (20122022) dengan menggunakan model Thomas-Fiering. Data curah hujan bangkitan ini digunakan untuk membuat neraca air. Neraca air menggambarkan kondisi surplus dan defisit ketersediaan lengas tanah. Data analisis neraca air menunjukkan bahwa masa tanam tebu yang tepat adalah September- Agustus dan Oktober-September.

Kata kunci: Masa Tanam, Pembangkitan Data Curah Hujan Bulanan, Neraca Air

\section{PENDAHULUAN}

Pemanasan global (global warming) telah mengubah kondisi iklim global, regional, dan lokal. Perubahan iklim global akan menyebabkan berubahnya pola curah hujan, bergesernya awal musim hujan/pergeseran musim serta makin meningkatnya intensitas kejadian iklim ekstrim (anomaly iklim) (Anonim, 2009).

Curah hujan merupakan unsur iklim yang besar pengaruhnya terhadap suatu sistem usahatani, terutama pada lahan kering dan tadah hujan. Curah hujan sangat menentukan pola dan intensitas tanam yang dicirikan oleh growing season suatu lahan. Menurut Bannu (2003) cit. 
Hermawan (2010), curah hujan di Indonesia khususnya Pulau Jawa dipengaruhi oleh sistem Monsun Asia-Australia yang menyebabkan wilayah ini memiliki satu puncak hujan maksimum, yaitu pada bulan Januari, Februari atau Desember.

Masa tanam memegang peranan penting dalam sistem budidaya pertanian terutama pada lahan non-irigasi. Pada lahan kering, pemilihan masa tanam yang tepat dapat meminimalkan resiko tanaman mengalami cekaman kekeringan (water stress) pada fase kritis, mengkuantifikasi volume air yang harus ditambahkan untuk mencapai indeks kebutuhan air yang diinginkan, serta memaksimalkan intensitas tanam (Surmaini dan Irianto, 2003). Waktu tanam dapat ditentukan berdasarkan waktu terjadinya surplus air dan lengas tanah dari hasil neraca air baik dekade maupun bulanan.

Menurut Pusat Penelitian dan Pengembangan Perkebunan (2010), dalam masa pertumbuhan tanaman tebu (Saccharum officinarum L.) membutuhkan banyak air, sedangkan saat masak tanaman tebu membutuhkan keadaan kering agar pertumbuhan terhenti. Intensitas hujan yang tinggi akan menyebabkan pertumbuhan terus terjadi dan tidak ada kesempatan untuk masak sehingga rendemen menjadi rendah.

Tujuan penelitian ini adalah untuk menentukan masa tanam tebu di Kecamatan Kalasan, Sleman pada tahun 2012-2022 berdasarkan pembangkitan data curah hujan bulanan dan analisis neraca air. Hasil penelitian ini diharapkan dapat menjadi informasi atau acuan dalam menentukan masa tanam tebu di Kecamatan Kalasan, Sleman sehingga dapat mengurangi resiko yang disebabkan oleh variabel curah hujan.

\section{BAHAN DAN METODE}

\section{Data}

a. Curah hujan bulanan Kecamatan Kalasan, Sleman periode 2002 - 2011

b. Suhu, kelembaban, kecepatan angin dan lama penyinaran

c. Kapasitas lapangan dan titik layu permanen

d. Koefisien tanaman tebu

\section{Metode}

\section{a. Uji Homogenitas Data}

Buishand (1982) mengatakan bahwa pengujian homogenitas dapat didasarkan pada jumlah parsial disesuaikan atau kumulatif penyimpangan dari rerata. Pengujian homogenitas ini sering juga disebut Rescaled Aajusted Partial Sums (RAPS).

$$
\begin{aligned}
& S_{0}^{*}=0 \quad S_{k}^{*}=\sum_{i=1}^{k}\left(Y_{i}-\bar{Y}\right), \mathrm{k}=1, \ldots \mathrm{n} \\
& S_{k}^{* *}=S_{k}^{*} / D_{y}, \mathrm{k}=0, \ldots \mathrm{n} \\
& D_{y}^{2}=\frac{\sum_{i}^{n}\left(Y_{i}-\bar{Y}\right)^{2}}{n}
\end{aligned}
$$

b. Uji Validitas Model (Uji- $t$ )

Menurut Walpole dan Myers (1995), hipotesis dalam uji- $t$ berpasangan dituliskan secara statistik sebagai berikut:

$$
\begin{aligned}
& \mathrm{H}_{0}: \mu 1=\mu 2 \\
& \mathrm{H}_{1}: \mu 1 \text { 丸12 }
\end{aligned}
$$

Uji statistik berbentuk:

$$
\begin{aligned}
& t=\frac{\bar{d}-\mu_{D}}{s_{\bar{d}}} \\
& s_{\bar{d}}=\frac{s_{d}}{\sqrt{n}} ; \quad s_{d}=\sqrt{\frac{\sum(d-\bar{d})^{2}}{n-1}}
\end{aligned}
$$

Kriteria pengujiannya adalah terima $\mathrm{H}_{0}$ jika $-t_{\alpha / 2}<t<t_{\alpha / 2}$

\section{c. Uji Korelasi Linear Sederhana}

Persamaan korelasi linear dituliskan sebagai berikut:

$$
r=\frac{\sum x y}{\sqrt{\left(\sum x^{2}\right)\left(\sum y^{2}\right)}}
$$

Koefisien korelasi dinyatakan berbeda nyata (variabel-variabel memiliki korelasi) pada taraf $\alpha$ apabila nilai absolut dari $r_{\text {hitung }}>r_{\text {tabel }}$ pada taraf nyata $\alpha$.

d. Pembangkitan Data Curah Hujan Dengan Model Thomas-Fiering

Menurut Clarke (1973), model ThomasFiering secara implisit memungkinkan untuk ketidakstasioneran yang diamati pada data curah hujan bulanan. Model ini terdiri dari dua belas persamaan regresi linear. Persamaan model Thomas-Fiering dituliskan sebagai berikut:

$$
R_{i+1}=\bar{R}_{j+1}+b_{j}\left(R_{i}-\bar{R}_{j}\right)+Z_{i} S_{j+1} \sqrt{1-r_{j}^{2}}
$$


$R_{\mathrm{i}}$ adalah curah hujan selama bulan $i, R_{i+1}$ adalah curah hujan selama bulan $i+1$, adalah rata-rata curah hujan selama bulan $j$, adalah rata-rata curah hujan selama bulan $j+1, b j$ adalah koefisien regresi untuk memperkirakan curah hujan pada bulan $j+1$ dari bulan $\mathrm{j}, \mathrm{Zi}$ adalah random normal deviate N $(0,1), S i$ adalah standar deviasi curah hujan pada bulan $j+1, r j$ adalah koefisien korelasi antara curah hujan bulan $j$ dan bulan $j+1$.

e. Menentukan Masa Tanam Berdasarkan Neraca Air

Perhitungan neraca air tanaman dapat dilakukan dengan langkah-langkah sebagai berikut:

1) Menghitung curah hujan efektif $\left(P_{\text {eff }}\right)$

2) Menghitung evapotranspirasi potensial $\left(E T_{\mathrm{o}}\right)$ dengan menggunakan program Cropwat.

3) Menghitung evapotranspirasi tanaman $E T_{c}=E T_{\mathrm{a}}=E T_{\mathrm{o}} \cdot K_{\mathrm{c}}$

4) Menghitung selisih $P_{\text {eff }}-E T_{\mathrm{c}}$

5) Nilai-nilai negatif pada langkah (4) diakumulasi bulan demi bulan sebagai nilai Accumulation Potential of Water Loss (APWL).

6) Menghitung Kandungan Lengas Tanah (KLT) (Mardawilis, dkk. 2011):

$$
K L T=K L x k^{a}
$$

Keterangan :

$K L \quad=$ kapasitas lapangan $(\mathrm{mm})$

$a \quad=$ harga mutlak APWL

$k=$ nilai ketetapan, $k=p o+p i / K L$.

po $=1,000412351$,

$p i=-1,073807306$

Nilai kapasitas lapangan diperoleh berdasarkan data lapangan.

7) Menghitung perubahan kadar lengas $\operatorname{tanah}(d K L T)$

$$
d K L T_{i}=K L T_{i}-K L T_{i-1}
$$

Dengan: $i=$ bulan $1,2, \ldots, 12$

Nilai positif menyatakan perubahan kandungan air tanah yang berlangsung pada Peff > ETc (musim hujan). Bila Peff $<E T c$ atau $d K L T$ negatif, maka seluruh curah hujan dan sebagian $K L T$ akan dievapotranspirasi.

8) Menentukan defisit dan surplus. Defisit terjadi pada saat Peff $<E T c$, yang berarti berkurangnya air untuk dievapotranspirasikan, sedangkan surplus berarti kelebihan air ketika Peff > ETc.

Surplus/Defisit $=$ Peff-ETc $-d K L T$ (10)

Tanda positif menunjukkan kondisi surplus, sedangkan tanda negatif menunjukkan kondisi defisit.

9) Menghitung aliran permukaan (surface runoff)

Menurut Nasir dan Effendi (2000) cit. Firmansyah (2010), persamaan Surface runoff adalah sebagai berikut:

Surface runoff bulan pertama:

$\mathrm{SROn}=50 \% . \mathrm{Sn}$

Surface runoff bulan berikutnya:

$\mathrm{SROn}=50 \%(\mathrm{Sn}+\mathrm{SROn}-1)$

Nilai $50 \%$ adalah koefisien surface runoff, $S n$ adalah surplus bulan $n$, SROn-1 adalah surface runoff bulan sebelumnya.

10) Menyusun grafik neraca air untuk setiap awal musim tanam.

11) Menentukan masa tanam tebu yang tepat untuk sepuluh tahun mendatang dengan melihat ketersediaan air serta kebutuhan air tanaman tiap fase pertumbuhan.

\section{HASIL DAN PEMBAHASAN}

\section{Sifat Fisik Tanah}

Jenis tanah pada daerah ini merupakan Entisol. Data analisis tekstur menunjukkan bahwa tanah di lokasi penelitian mempunyai kandungan pasir berkisar $81-91 \%$, debu 7-21\%, dan klei $1-4 \%$. Persentase ini dalam diagram segitiga tekstur tanah termasok jenis pasir (sandy) dan pasir geluhan (loamy)sand) (Hanafiah, 2010).

\section{Karakteristik Iklim}

Iklim daerah penelitian merupakan tipe iklim D dengan karakteristik sedang. Pola curah hujan menunjukkan bahwa pola curah hujan yang terjadi adalah tipe Monsun. Suhu udara maksimum ratarata bulanan berkisar antara $31,0-32,7^{\circ} \mathrm{C}$, 
sedangkan suhu minimumnya berkisar antara $21,7-24,2^{\circ} \mathrm{C}$. Kelembaban udara berkisar antara $73-85 \%$, dengan kelembaban udara maksimum terjadi pada bulan Februari dan kelembaban udara minimum terjadi pada bulan September. Kecepatan angina di daerah ini berkisar antara $5,50-8,42 \mathrm{~km} / \mathrm{jam}$, sedangkan lamanya matahari bersinar adalah sekitar 4,49-7,48 jam.

\section{Hasil Uji Homogenitas Data, Uji Validitas Model dan Uji Korelasi}

\section{Linear Sederhana}

Tabel 1. Hasil Uji Homogenitas Data

\begin{tabular}{cccc}
\hline & Hasil Perhitungan & Nilai Tabel & Keterangan \\
\hline$Q \sqrt{\overline{\bar{n}}}$ & 0,98 & 1,29 & Data homogen \\
$R \sqrt{\frac{\bar{n}}{\bar{n}}}$ & 0,98 & 1,38 & Data homogen \\
\hline
\end{tabular}

Hasil uji korelasi menunjukkan bahwa curah hujan hasil bangkitan memiliki korelasi dengan curah hujan hasil observasi di lapangan. Hasil perhitungan menunjukkan nilai koefisien korelasi untuk tahun 2010, yaitu $r=0,845$, sedangkan untuk tahun 2011, yaitu $r=0,947$. Nilai $r$ table pada taraf nyata $5 \%$ dan $1 \%$ dengan derajat bebas
Uji homogenitas data menunjukkan bahwa data curah hujan tahun 2002-2011 adalah homogen sehingga dapat digunakan untuk membangkitkan data curah hujan tahun 2012- 2022. Hasil uji homogenitas data dapat dilihat pada Tabel 1.

Uji validitas model dengan menggunakan uji- $t$ juga menunjukkan bahwa model Thomas-Fiering dapat digunakan untuk membangkitkan data curah hujan bulanan. Hasil uji $t$ yang dilakukan menunjukkan nilai $t_{\text {hitung }}$ sebagai berikut: $4,437<3,236<4,437$ untuk tahun 2010 dan $-4,437<$ $3,900<4,437$ untuk tahun 2011.

Tabel 2. Data Curah Hujan Bangkitan Tahun 2012 - 2022

\begin{tabular}{|c|c|c|c|c|c|c|c|c|c|c|c|}
\hline \multirow{2}{*}{ Bulan } & \multicolumn{11}{|c|}{ Curah hujan tahun (mm) } \\
\hline & 2012 & 2013 & 2014 & 2015 & 2016 & 2017 & 2018 & 2019 & 2020 & 2021 & 2022 \\
\hline Januari & 466,7 & 369,1 & 230,8 & 378,7 & 265,3 & 417,7 & 251,1 & 149,6 & 388,3 & 399,1 & 449,1 \\
\hline Februari & 268,8 & 350,5 & 413,3 & 434,3 & 454,2 & 432,1 & 352,7 & 395,2 & 391,0 & 287,3 & 351,4 \\
\hline Maret & 185,5 & 244,2 & 133,8 & 184,2 & 137,6 & 172,8 & 286,3 & 143,3 & 223,7 & 200,9 & 331,3 \\
\hline April & 241,7 & 159,7 & 63,7 & 140,1 & 54,5 & 131,4 & 167,6 & 46,7 & 179,2 & 158,9 & 110,9 \\
\hline Mei & 138,8 & 0,0 & 100,3 & 125,9 & 141,2 & 0,0 & 106,9 & 144,5 & 215,3 & 130,7 & 0,0 \\
\hline Juni & 0,0 & 9,5 & 9,8 & 0,7 & 15,0 & 32,1 & 0,0 & 0,0 & 0,0 & 0,0 & 16,0 \\
\hline Juli & 1,6 & 0,0 & 0,0 & 0,0 & 6,4 & 14,7 & 0,0 & 0,0 & 0,0 & 0,0 & 0,0 \\
\hline Agustus & 0,3 & 0,0 & 0,0 & 0,0 & 1,6 & 2,7 & 3,5 & 2,2 & 0,8 & 0,0 & 0,0 \\
\hline September & 21,1 & 0,0 & 0,0 & 22,7 & 25,8 & 28,2 & 2,6 & 0,0 & 0,0 & 0,0 & 0,0 \\
\hline Oktober & 112,6 & 103,4 & 68,9 & 79,7 & 114,6 & 68,8 & 81,4 & 0,0 & 80,4 & 42,5 & 69,5 \\
\hline November & 206,9 & 357,3 & 361,0 & 400,2 & 439,0 & 333,8 & 214,7 & 265,9 & 241,1 & 370,3 & 348,7 \\
\hline \multirow[t]{2}{*}{ Desember } & 328,6 & 387,9 & 461,7 & 514,4 & 511,0 & 365,1 & 162,0 & 392,2 & 231,9 & 261,8 & 432,3 \\
\hline & 1972,6 & 1981,6 & 1843,3 & 2280,9 & 2166,2 & 1999,4 & 1628,8 & 1539,6 & 1951,7 & 1851,5 & 2109,2 \\
\hline
\end{tabular}

\section{Evapotranspirasi Tanaman dan Koefisien Tanaman}

Laju evapotranspirasi tanaman dipengaruhi oleh tahap pertumbuhan dan kondisi lingkungan. Evapotranspirasi potensial $\left(E T_{o}\right)$ dipengaruhi oleh beberapa anasir iklim, seperti suhu, kelembaban,
10 adalah 0,576 dan 0,708 .

\section{Curah Hujan Bulanan Bangkitan}

Model Thomas-Fiering yang terdiri dari 12 persamaan regresi digunakan untuk membangkitkan data curah hujan bulanan. Data curah hujan bulanan tahun 2012-2022 dapat dilihat pada Tabel 2. 
Tabel 3. Nilai Evapotranspirasi Potensial (ETo ) Bulanan

\begin{tabular}{lcc}
\hline Bulan & $\boldsymbol{E T}_{\boldsymbol{O}}(\mathbf{m m} / \mathbf{h a r i})$ & $\boldsymbol{E T}_{\boldsymbol{O}}(\mathbf{m m} / \mathbf{b u l a n})$ \\
\hline Januari & 3,78 & 113,4 \\
Februari & 3,79 & 106,1 \\
Maret & 3,90 & 117,0 \\
April & 3,92 & 117,6 \\
Mei & 3,68 & 110,4 \\
Juni & 3,59 & 107,7 \\
Juli & 3,77 & 113,1 \\
Agustus & 4,21 & 126,3 \\
September & 4,49 & 134,7 \\
Oktober & 4,56 & 136,8 \\
November & 4,03 & 120,9 \\
Desember & 3,59 & 107,7 \\
\hline
\end{tabular}

Tabel 4. Nilai $k c$ Tanaman Tebu

\begin{tabular}{|c|c|c|c|c|c|}
\hline \multirow{2}{*}{$\begin{array}{l}\text { Umur Tanaman } \\
\text { (bulan) }\end{array}$} & \multirow{2}{*}{ Tahap Pertumbuhan } & \multicolumn{2}{|c|}{$\begin{array}{c}\text { Kelembaban Relatif } \\
>70 \%\end{array}$} & \multicolumn{2}{|c|}{$\begin{array}{c}\text { Kelembaban Relatif } \\
<70 \%\end{array}$} \\
\hline & & $\begin{array}{c}\text { Angin pelan } \\
\text { hingga moderat }\end{array}$ & Angin kencang & $\begin{array}{c}\text { Angin pelan } \\
\text { hingga moderat }\end{array}$ & Angin kencang \\
\hline $0-1$ & $\begin{array}{l}\text { Penanaman hingga } 25 \% \\
\text { tajuk lengkap }\end{array}$ & 0,55 & 0,60 & 0,40 & 0,45 \\
\hline$>1-2$ & $\begin{array}{l}25 \%-50 \% \text { tajuk } \\
\text { lengkap }\end{array}$ & 0,80 & 0,85 & 0,75 & 0,80 \\
\hline$>2-2,5$ & $\begin{array}{l}50 \%-75 \% \text { tajuk } \\
\text { lengkap }\end{array}$ & 0,90 & 0,95 & 0,95 & 1,00 \\
\hline$>2,5-4$ & $75 \%$ tajuk lengkap & 1,00 & 1,10 & 1,10 & 1,20 \\
\hline$>4-10$ & Puncak penggunaan & 1,05 & 1,15 & 1,25 & 1,30 \\
\hline$>10-11$ & Penuaan awal & 0,80 & 0,85 & 0,95 & 1,05 \\
\hline$>11-12$ & Pemasakan & 0,60 & 0,65 & 0,70 & 0,75 \\
\hline
\end{tabular}

Sumber: Doorenbos dan Pruitt (1975)

\section{Penentuan Masa Tanam Berdasarkan Neraca} Air

Varietas tebu yang ditanam di Kecamatan Kalasan, Sleman adalah tebu pasir. Tebu ini merupakan tebu berumur pendek (masak awal), yaitu kemasakan optimal dicapai pada umur 11 bulan (Tim Penulis PS, 1992). Para petani di daerah ini biasanya melakukan awal tanam menjelang musim hujan, yaitu pada bulan Mei hingga Juli dengan masa tebang sekitar bulan April hingga Juni. Awal tanam ini dilakukan dengan anggapan bahwa pada bulan Oktober hingga Maret, kebutuhan air pada fase vegetatif akan tercukupi.

Neraca air di suatu daerah menggambarkan potensi ketersediaan air dan potensi kebutuhan air pada suatu waktu tertentu. Perencanaan masa tanam tebu untuk tahun 2012-2022 menggunakan konsep neraca air dengan interval waktu bulanan; untuk tiap tahun disusun 12 bentuk neraca air berdasarkan12 variasi awal masa tanam. Data analisis neraca air yang digunakan untuk menentukan masa tanam yang tepat, yaitu pada saat kadar lengas tanah sesuai dengan kebutuhan tanaman tebu selama satu siklus musim tanam.

Data analisis neraca air menunjukkan bahwa pada tahun 2012, 2013, 2015, 2016, 2020 dan 2021, masa tanam terbaik adalah SeptemberAgustus. Tanaman tebu yang ditanam pada awal September umumnya mengalami defisit selama 2 bulan awal pertumbuhan. Tanaman tebu mengalami kecukupan lengas ketika tebu mulai berumur $3-7$ bulan, sedangkan pada umur lebih dari 7 bulan hingga panen tebu sudah mengalami kondisi kering. Kondisi ini baik untuk akumulasi sukrosa. Data analisis neraca air menunjukkan 
bahwa pada tahun 2014, 2017 - 2019, masa tanam terbaik adalah Oktober - September. Tanaman tebu yang ditanam pada awal Oktober ini akan mengalami defisit lengas pada bulan pertama pertumbuhannya. Tanaman tebu ini akan

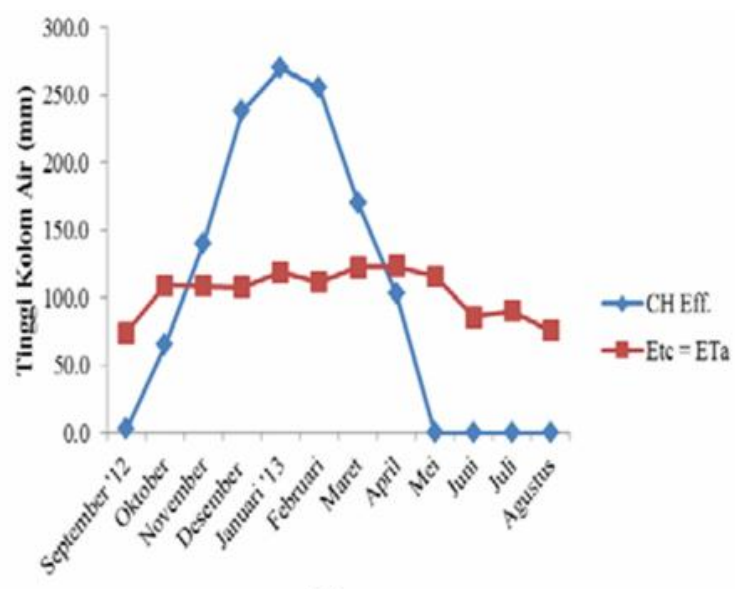

Bulan

Gambar 1. Neraca Air Sept. 2012 - Agst. 2013

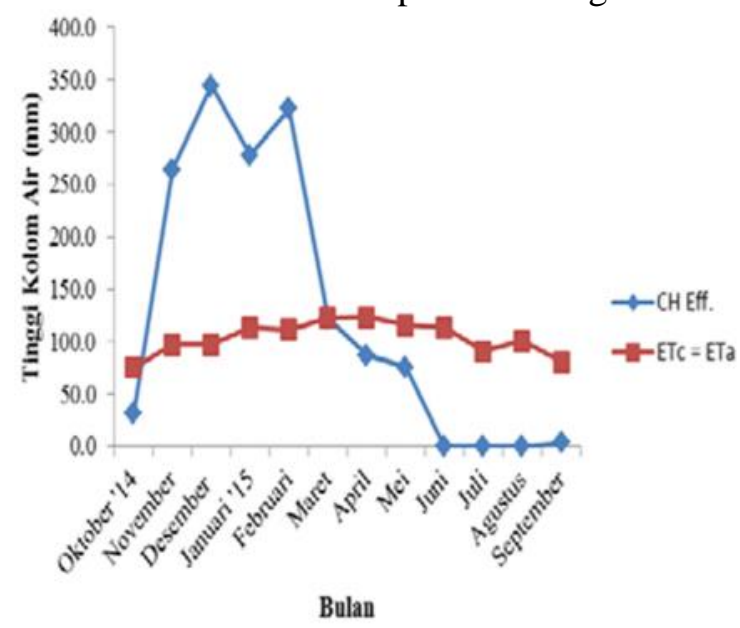

Gambar 3. Neraca Air Okt. 2014 - Sept. 2015

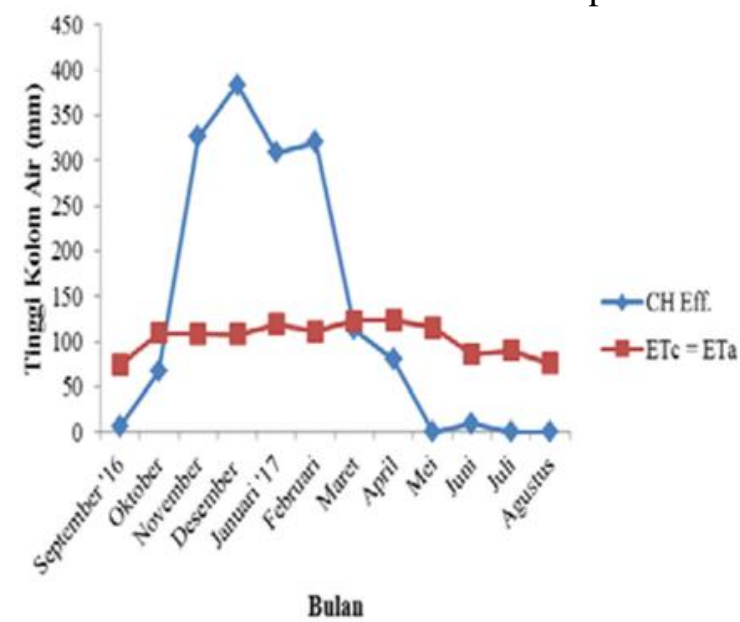

Gambar 5. Neraca Air Sept. 2016 - Okt. 2017 mengalami kecukupan lengas ketika memasuki umur 2- 7 bulan, setelah itu akan mengalami kondisi kering lagi hingga panen. Neraca air untuk perencanaan masa tanam tebu tahun $2012-2022$ dapat dilihat pada Gambar 1 hingga 10.

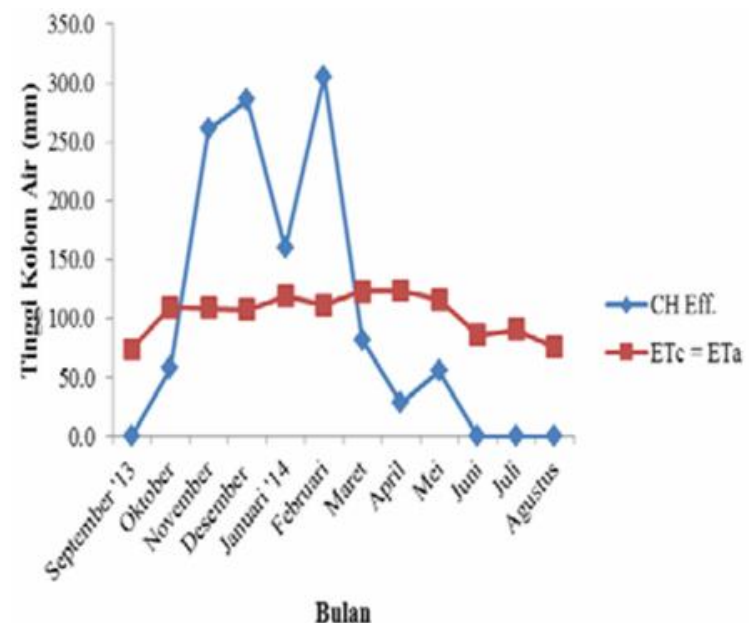

Gambar 2. Neraca Air Sept. 2013 - Agst. 2014

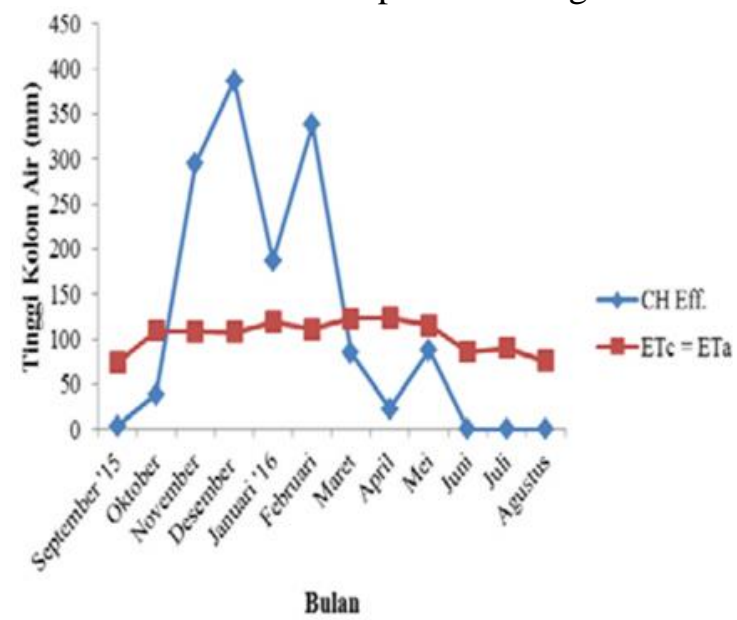

Gambar 4.Neraca Air Sept. 2015 - Agst. 2016

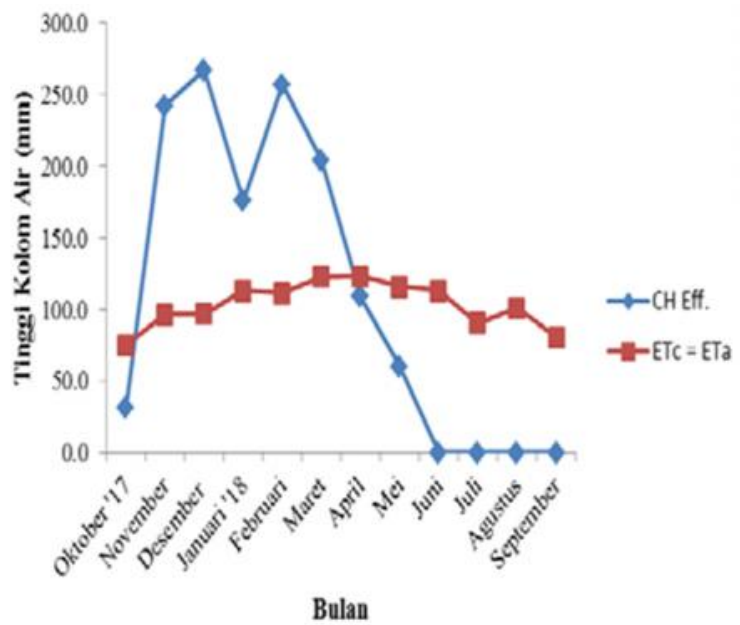

Gambar 6. Neraca Air Okt. 2017 - Sept. 2018 


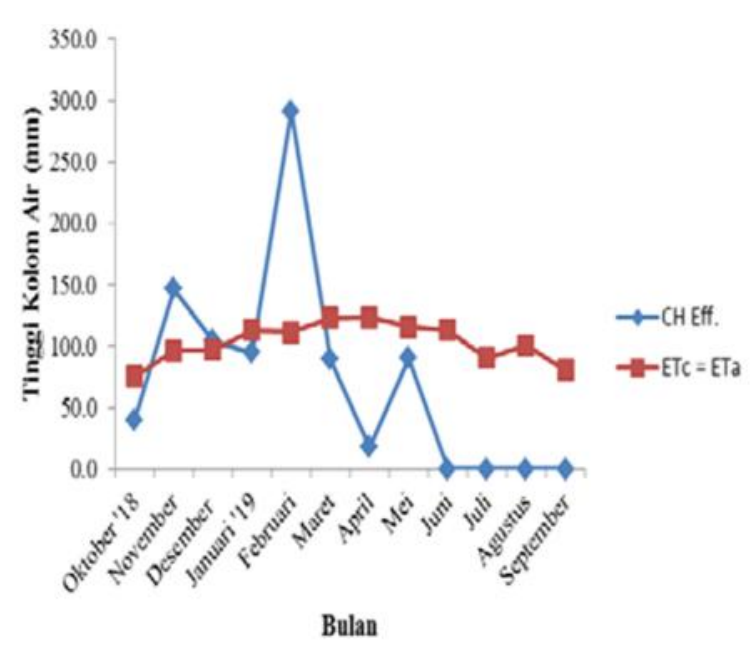

Gambar 7. Neraca Air Okt. 2018 - Sept. 2019

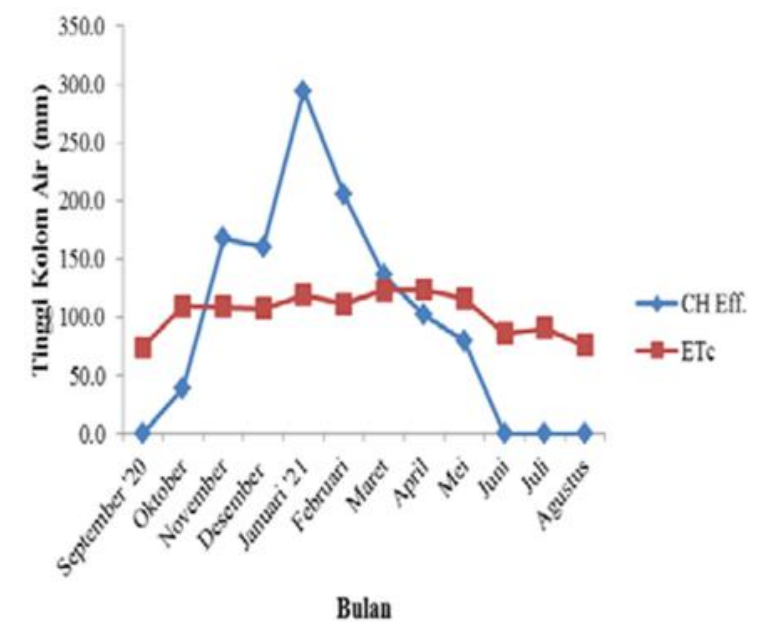

Gambar 9. Neraca Air Sept. 2020 - Okt. 2021

\section{KESIMPULAN}

1. Uji homogenitas data dan uji validitas data menunjukkan bahwa data curah hujan tahun 2002 - 2011 dan model Thomas-Fiering dapat digunakan untuk membangkitkan data curah hujan bulanan untuk tahun 2012 - 2022. Data curah hujan bulanan hasil bangkitan dapat digunakan untuk menentukan masa tanam tebu di Kecamatan Kalasan, Sleman.

2. Data curah hujan bulanan hasil bangkitan menunjukkan bahwa pada umumnya bulan basah berlangsung pada bulan Oktober - Mei, sedangkan bulan kering terjadi pada bulan Juni - September.

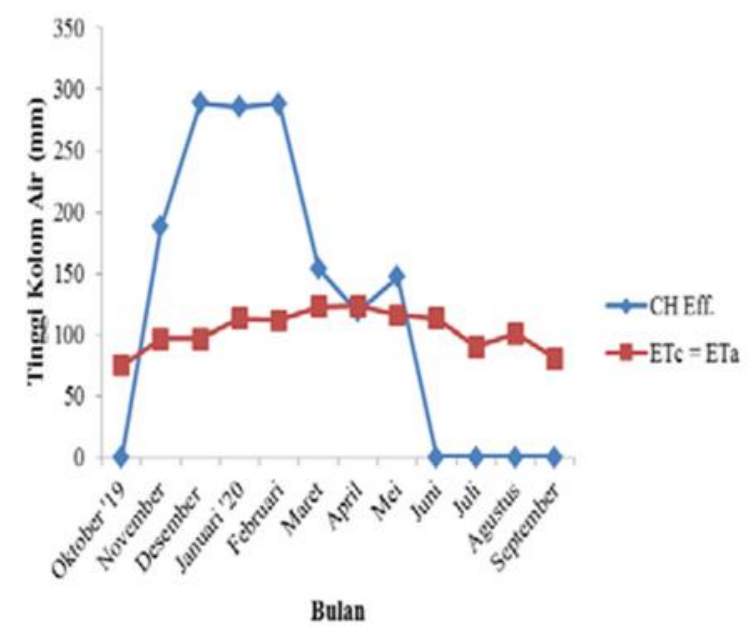

Gambar 8. Neraca Air Okt. 2019 - Sept. 2020

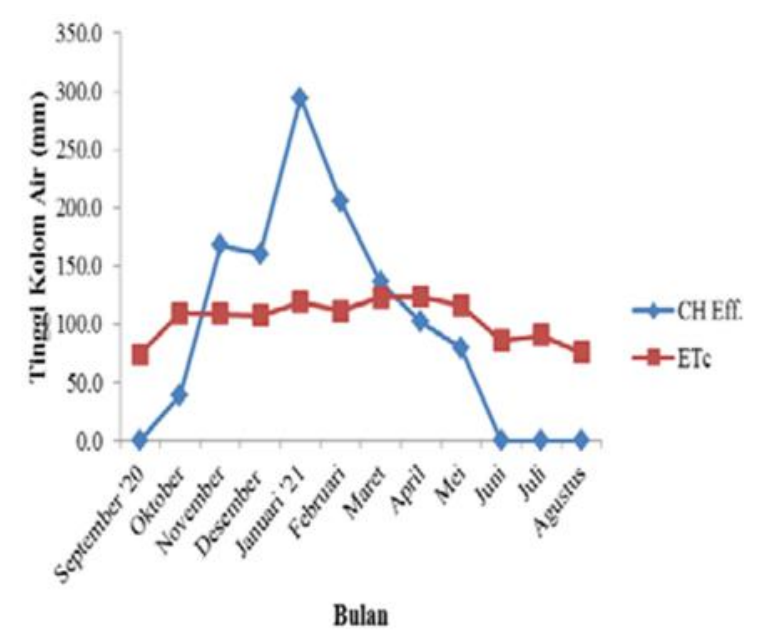

Gambar 10. Neraca Air Okt. 2021 - Sept. 2022

Ketersediaan lengas tanah bagi tanaman tebu tidak hanya ditentukan oleh faktor intensitas curah hujan. Faktor lain yang juga sangat berpengaruh terhadap ketersediaan lengas tanah adalah sifat tanah dan evapotranspirasi pada setiap fase pertumbuhan tanaman.

3. Masa tanam yang selama ini diterapkan petani tebu di Kecamatan Kalasan, Sleman kurang tepat. Para petani umumnya menanam tebu pada bulan Mei - Juli dan memanennya pada bulan April - Juni. Data analisis neraca air tahun 2012 - 2021 menunjukkan 2 masa tanam yang baik untuk diterapkan dalam budidaya tebu, yaitu masa tanam September-Agustus dan masa tanam 
Oktober-September. Masa tanam September-Agustus terjadi pada tahun 2012, 2013, 2015, 2016, 2020, dan 2021. Masa tanam Oktober-September terjadi pada tahun 2014, 2017-2019. Perubahan masa tanam diharapkan meningkatkan rendemen yang dihasilkan.

\section{DAFTAR PUSTAKA}

Anonim. 2009. "Pedoman Umum": Sekolah Lapang Iklim. Direktorat Pengelolaan Air. Direktorat Jendral Pengelolaan Lahan dan Air dan Departemen Pertanian.

Bannu. 2003. Analisis Interaksi Monsun, Enso, dan Dipole Mode serta Kaitannya Dengan Variabilita Curah Hujan dan Angin Permukaan di Benua Maritim Indonesia. Tesis Magister. ITB. Bandung dalam Hermawan, E. 2010. Pengelompokkan Pola Curah Hujan Yang Terjadi di Beberapa Kawasan P.Sumatera Berbasis Hasil Analisis Teknik Spektral. Jurnal Meteorologi dan Geofisika, Volume 11, Nomor 2, Halaman 75-84.

Buishand, T.A. 1982. Some Methods For Testing The Homogeneity of Rainfall Records. Journal of Hydrology. Volume 58,(1-2).1127.

Clarke, R.T. 1973. Mathematical Models In Hydrology. FAO of The United Nations. Rome.

Doorenbos, J. dan W.O. Pruitt. 1975. Guidelines For Predicting Crop Water Requirement. FAO Irrigation and Drainage Paper No.24. Rome.
Hanafiah, K. A. 2006. Dasar-dasar Statistika:Aneka Bidang Ilmu Pertanian dan Hayati. Penerbit: PT Raja Grafindo. Jakarta.

Mardawilis, P. Sudira, B. H. Sunarminto, dan D. Shiddieq. 2011. Analisis Neraca Air Untuk Pengembangan Tanaman Pangan Pada Kondisi Iklim Yang Berbeda. Agritech, Volume 31, Nomor 2, Mei 2011.

Nasir, A. A. dan S. Effendi. 2000. Konsep Neraca

Air Untuk Penentuan Pola Tanam. Kapita Selekta Agroklimat (Ed. Y. Koesmaryono, Impron, Y. Sugiyarto) Jurusan Geofisika dan Meteorologi Fakultas Matematika dan IPA. Institut Pertanian Bogor dalam Firmansyah, M. A. 2010. Teori Dan Praktik Analisis Neraca Air Untuk Menunjang Tugas Penyuluh Pertanian Di Kalimantan Tengah. Makalah Pelatihan Agribisnis Pertanian untuk Analisis Iklim. Palangkaraya.

Pusat Penelitian dan Pengembangan Perkebunan. 2010. Budidaya dan Pasca Panen Tebu. Eska Media. Jakarta.

Surmaini, E.dan G. Irianto. 2003. Anomali Iklim, Evaluasi Masa Tanam, Tingkat Kehilangan Hasil Dan Pengaturan Sistem Produksi Pertanian Di Kalimantan Timur. Berita Biologi, Volume 6, Nomor 6, Desember 2003.

Tim Penulis PS. 1992. Pembudidayaan Tebu di Lahan Sawah dan Tegalan. Penerbit: PT. Penebar Swadaya. Jakarta.

Walpole, R. E. dan R. H. Myers. 1995. Ilmu Peluang Dan Statistika Untuk Insinyur Dan Ilmuwan, Edisi Keempat (diterjemahkan oleh RK. Sembiring). Penerbit ITB. Bandung. 